\title{
Influence of biomass burning plumes on HONO chemistry in eastern China
}

\author{
W. Nie ${ }^{1,2}$, A. J. Ding ${ }^{1,2}$, Y. N. Xie ${ }^{1,2}$, Z. Xu ${ }^{3}$, H. Mao ${ }^{1,2,5}$, V.-M. Kerminen ${ }^{4}$, L. F. Zheng ${ }^{1,3}$, X. M. Qi ${ }^{1,2}$, X. Huang ${ }^{1,2}$, \\ X.-Q. Yang ${ }^{1,2}$, J. N. Sun ${ }^{1,2}$, E. Herrmann ${ }^{1}$, T. Petäjä ${ }^{4}$, M. Kulmala ${ }^{4}$, and C. B. Fu ${ }^{1,2}$ \\ ${ }^{1}$ Institute for Climate and Global Change Research \& School of Atmospheric Sciences, Nanjing University, \\ Nanjing, 210093, China \\ ${ }^{2}$ Collaborative Innovation Center of Climate Change, Jiangsu Province, China \\ ${ }^{3}$ Environment Research Institute, Shandong University, Jinan, China \\ ${ }^{4}$ Division of Atmospheric Sciences, Department of Physics, University of Helsinki, 00014 Helsinki, Finland \\ ${ }^{5}$ Department of Chemistry, State University of New York College of Environmental Science and Forestry, \\ Syracuse, New York, USA
}

Correspondence to: A. J. Ding (dingaj@nju.edu.cn)

Received: 2 March 2014 - Published in Atmos. Chem. Phys. Discuss.: 21 March 2014

Revised: 2 December 2014 - Accepted: 29 December 2014 - Published: 2 February 2015

\begin{abstract}
Nitrous acid (HONO) plays a key role in atmospheric chemistry by influencing the budget of hydroxyl radical $(\mathrm{OH})$. In this study, a two-month measurement of HONO and related quantities were analyzed during a biomass burning season in 2012 at a suburban site in the western Yangtze River delta, eastern China. An overall high HONO concentration with the mean value of $0.76 \mathrm{ppbv}(0.01 \mathrm{ppbv}$ to $5.95 \mathrm{ppbv}$ ) was observed. During biomass burning (BB) periods, both $\mathrm{HONO}$ concentration and $\mathrm{HONO} / \mathrm{NO}_{2}$ ratio were enhanced significantly (more than a factor of $2, p<0.01$ ) compared with non-biomass burning (non-BB) periods. A correlation analysis showed that the HONO in BB plumes was more correlated with nitrogen dioxide $\left(\mathrm{NO}_{2}\right)$ than that with potassium (a tracer of $\mathrm{BB}$ ). Estimation by the method of potassium tracing suggests a maximum contribution of $17 \pm 12 \%$ from BB emission to the observed HONO concentrations, and the other over $80 \%$ of the observed nighttime HONO concentrations during BB periods were secondarily produced by the heterogeneous conversion of $\mathrm{NO}_{2}$. The $\mathrm{NO}_{2}$-to-HONO conversion rate $\left(C_{\mathrm{HONO}}\right)$ in $\mathrm{BB}$ plumes was almost twice as that in non-BB plumes $\left(0.0062 \mathrm{hr}^{-1}\right.$ vs. $0.0032 \mathrm{hr}^{-1}$ ). Given that the residence time of the $\mathrm{BB}$ air masses was lower than that of non-BB air masses, these results suggest $\mathrm{BB}$ aerosols have higher $\mathrm{NO}_{2}$ conversion potentials to form HONO than non-BB aerosols. A further analysis based on comparing the surface area at similar particle
\end{abstract}

mass levels and $\mathrm{HONO} / \mathrm{NO}_{2}$ ratios at similar surface area levels suggested larger specific surface areas and higher $\mathrm{NO}_{2}$ conversion efficiencies of BB aerosols. A mixed plume of $\mathrm{BB}$ and anthropogenic fossil fuel (FF) emissions was observed on 10 June with even higher HONO concentrations and $\mathrm{HONO} / \mathrm{NO}_{2}$ ratios. The strong $\mathrm{HONO}$ production potential (high $\mathrm{HONO} / \mathrm{NO}_{2}$ to $\mathrm{PM}_{2.5}$ ratio) was accompanied with a high sulfate concentration in this plume, suggesting a promotion of mixed aerosols to the HONO formation. In summary, our study suggests an important role of BB in atmospheric chemistry by affecting the HONO budget. This can be especially important in eastern China, where agricultural burning plumes are inevitably mixed with urban and industrial pollution.

\section{Introduction}

Nitrous acid (HONO) is an important constituent in the troposphere due to its role in hydrogen oxide $\left(\mathrm{HO}_{\mathrm{x}}\right)$ cycling (Platt et al., 1980; Kleffmann, 2007; Hofzumahaus et al., 2009; Elshorbany et al., 2012). The photolysis of HONO provides a daytime source of hydroxyl radical $(\mathrm{OH})$, which controls the daytime oxidation capacity and consequently influences the ozone $\left(\mathrm{O}_{3}\right)$ chemistry and secondary organic aerosol (SOA) formation. This process is especially impor- 
tant in the early morning when contributions from other $\mathrm{OH}$ sources, like $\mathrm{O}_{3}$ photolysis, are still small (Alicke et al., 2002; Kleffmann et al., 2005; Elshorbany et al., 2010).

The sources of atmospheric HONO, including direct emission from fossil fuel combustion (Kurtenbach et al., 2001) and soil ( $\mathrm{Su}$ et al., 2011), homogeneous gas phase reactions and heterogeneous processes on the surface of atmospheric aerosols and the ground (Harrison and Collins, 1998; Longfellow et al., 1999; Stutz et al., 2002; VandenBoer et al., 2013), are hitherto not well understood. Among these sources, heterogeneous processes are commonly accepted as the least understood pathway to the production of HONO. For example, nitrogen dioxide $\left(\mathrm{NO}_{2}\right)$ can be converted to HONO on the ground (Harrison and Kitto, 1994), wet surfaces (Finlayson-Pitts et al., 2003), soot particles (Ammann et al., 1998; Kalberer et al., 1999; Kleffmann and Wiesen, 2005), and organic substrates (Bröske et al., 2003; Ammann et al., 2005). These processes have been considered the primary contributor to nocturnal HONO formation, but they cannot sustain the frequently observed elevated daytime HONO concentration levels (Kleffmann, 2007; Sörgel et al., 2011; Li et al., 2012, and references therein). Recently, several heterogeneous and possibly photo-enhanced processes have been demonstrated that might play an important role in daytime HONO formation (George et al., 2005; Stemmler et al., 2006; Ndour et al., 2008; Nie et al., 2012; Langridge et al., 2009; Bedjanian and El Zein, 2012). However, although these studies have drawn a clearer picture of HONO chemistry, there are still large knowledge gaps in HONO sources. The heterogeneous production of HONO in the atmosphere by a variety of mechanisms is still under debate.

Biomass burning is a major source of atmospheric aerosol particles (Janhäll et al., 2010) and trace gases (Andreae and Merlet, 2001; Burling et al., 2010), consequently influencing climate and air quality. Recent studies have connected HONO chemistry to biomass burning (BB) via both direct HONO emissions and emissions of soot particles (Roberts et al., 2010; Veres et al., 2010). Although high emission ratios of HONO have been detected in laboratory fires (Burling et al., 2010; Veres et al., 2010), the mixing ratio of HONO in aged BB plumes is expected to be relatively independent of its direct emissions due to the rapid dilution and photolysis for primary HONO during atmospheric transport. Soot particles, as one major component in $\mathrm{BB}$ plumes, have been demonstrated to be an effective media to convert $\mathrm{NO}_{2}$ to HONO (Kleffmann et al., 1999; Aumont et al., 1999; Prince et al., 2002; Kleffmann and Wiesen, 2005; Aubin and Abbatt, 2007), especially in the case that aged soot particles can be re-activated in the present of light (Monge et al., 2010) and play a continuous role in the HONO chemistry. These processes may significantly influence the HONO chemistry during a $\mathrm{BB}$ period, but their exact roles are rarely demonstrated in the real atmosphere, especially when BB aerosols are mixed with anthropogenic pollutants.

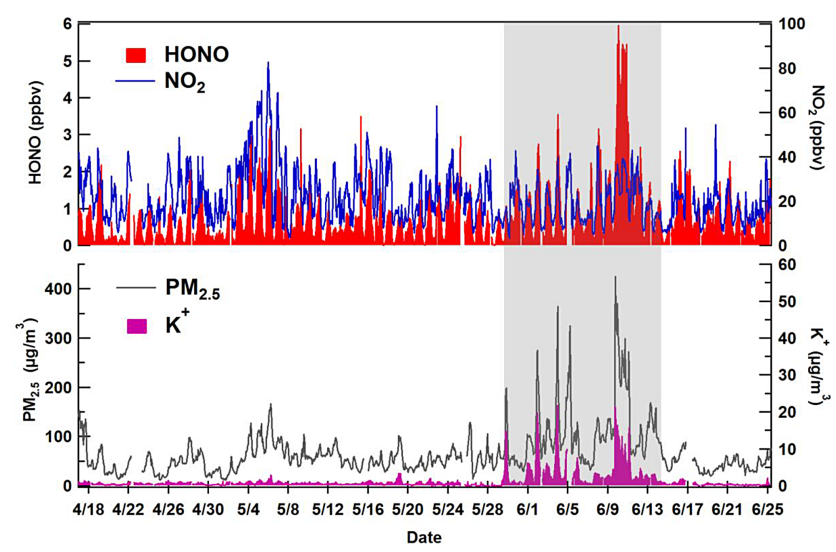

Figure 1. Temporal variation of the concentrations of $\mathrm{HONO}, \mathrm{NO}_{2}$ $\mathrm{PM}_{2.5}$ mass and potassium, at the SORPES station during late April-June 2012. BB episodes mostly occurred during May and early June (shaded in the figure).

In this study, a two-month measurement campaign was conducted during the intensive BB (burning of wheat straw) period (April-June 2012) at the SORPES station (Station for Observing Regional Processes of the Earth System) in the western Yangtze River delta (YRD) of East China (Ding et al., 2013c). Several HONO-related quantities were measured, with the aim to investigate the HONO chemistry in the YRD, a region undergoing rapid urbanization and industrialization. Special attention was paid to the impact of BB plumes and mixed plumes of agricultural burning and fossil fuel (FF) emissions on HONO formation after long-range transport. In the following, the general features related to HONO during the campaign were first described. The differences in HONO formation between the BB events and nonBB events were then investigated. Finally, the influences of mixed plumes of intensive BB and FF emission (Ding et al., 2013b) on HONO formation were discussed.

\section{Experimental methodologies}

\subsection{Field campaign}

The field campaign was conducted from late April-June 2012 at the SORPES "flagship" central site in Xianlin of Nanjing (Ding et al., 2013c). It is a regional background site, located on top of a hill $\left(118^{\circ} 57^{\prime} 10^{\prime \prime} \mathrm{E}, 32^{\circ} 07^{\prime} 14^{\prime \prime} \mathrm{N}\right.$; 40 ma.s.1.) in the Xianlin campus of Nanjing University and about $20 \mathrm{~km}$ east of the suburban Nanjing city (see Fig. 1 in Ding et al., 2013c). A suite of trace gases, aerosols and meteorological quantities were measured, with more detailed descriptions found in Ding et al. $(2013 \mathrm{~b}, \mathrm{c})$. The present study is focused on $\mathrm{HONO}$ and related quantities, including $\mathrm{NO}_{2}$, $\mathrm{NO}_{\mathrm{x}}, \mathrm{CO}, \mathrm{SO}_{2}, \mathrm{PM}_{2.5}$ mass, total water-soluble ions (WSIs), potassium ions $\left(\mathrm{K}^{+}\right)$, sulfate $\left(\mathrm{SO}_{4}^{2-}\right)$, and particle surfacearea size distribution over the size range of $6-800 \mathrm{~nm}$. 


\subsection{Measurement techniques}

The HONO concentration was measured with a Monitor for Aerosols and Gases in Air (MARGA, Metrohm Co.), which includes a wet rotating denuder (WRD) (Spindler et al., 2003; Su et al., 2008; Makkonen et al., 2012) connected to an ion chromatograph (IC, Metrohm USA, Inc., Riverview, FL). The time resolution of this measurement is $1 \mathrm{~h}$. There were 1608 hourly samples during the campaign. The WRD consists of two concentric glass cylinders whose wall is coated with $10 \mathrm{ppm} \mathrm{H}_{2} \mathrm{O}_{2}$ solution to absorb $\mathrm{HONO}$ and other gases. The liquid sample streams from the WRD are drawn into $25 \mathrm{~mL}$ syringes before being injected into the IC system. The residence time of sampling air is about $4.5 \mathrm{~s}$ in the sampling tubes and about $0.2 \mathrm{~s}$ in WRD.

Other measurement techniques are described briefly as follows. The fine particle mass concentration $\left(\mathrm{PM}_{2.5}\right)$ was continuously measured with a combined technique of light scattering photometry and beta radiation attenuation (Thermo Scientific SHARP Monitor Model 5030). Sulfate $\left(\mathrm{SO}_{4}^{2-}\right)$ and potassium ions $\left(\mathrm{K}^{+}\right)$concentrations in $\mathrm{PM}_{2.5}$ were measured with the MARGA system (Ding et al., 2013b). $\mathrm{NO}_{2}$ was converted to nitric oxide (NO) with a molybdenum oxide (MoO) catalytic converter inside the instrument and measured with a chemiluminescence analyzer (TEI model 42i). It should be noted that the technique of using a molybdenum converter to measure $\mathrm{NO}_{2}$ may overestimate its ambient concentrations during daytime due to the potential conversion of species other than $\mathrm{NO}_{2}$ (e.g., peroxyacetyl nitrate (PAN)) to NO (Xu et al., 2013). However, the interference is much lower at nighttime without photochemical reaction. Total reactive nitrogen oxides $\left(\mathrm{NO}_{\mathrm{y}}\right)$ was measured with an externally placed molybdenum converter and a $\mathrm{NO}$ analyzer. The sulfur dioxide $\left(\mathrm{SO}_{2}\right)$ concentration was measured with a pulsed UV fluorescence analyzer (TEI model 43i). Detailed information can be found in Ding et al. (2013c).

\subsection{Sampling artifacts and data correction}

The sampling artifacts of $\mathrm{HONO}$ measurement with the WRD method are mainly caused by the $\mathrm{NO}_{2}$ conversion on the surface of the sampling tube and the WRD (interference 1) and the reaction of $\mathrm{NO}_{2}$ with $\mathrm{S}$ (IV) in the absorption solution in WRD (interference 2) (Spindler et al., 2003; Barnes and Rudziński, 2012). In this study, 10 ppm of $\mathrm{H}_{2} \mathrm{O}_{2}$ was used as the absorption solution for the MARGA system, which can oxidize the S (IV) very quickly to form $\mathrm{H}_{2} \mathrm{SO}_{4}$, and thus can avoid the interference 2 induced by the reaction of $\mathrm{NO}_{2}$ with $\mathrm{S}$ (IV) (Genfa et al., 2003). In addition, the formation of $\mathrm{H}_{2} \mathrm{SO}_{4}$ can acidify the absorption solution, which will reduce the interference 1 in WRD by suppressing the absorption and reaction of $\mathrm{NO}_{2}$ on the surface of the absorption solution (Kleffmann et al., 2002). Therefore, in this study, the interference of HONO measurement should be mainly from the $\mathrm{NO}_{2}$ conversion on the surface of the sampling tube (part of interference 1). Here, to avoid the possible overestimation, we corrected the data set with the following formula recommended by an inter-comparison study on the HONO measurement between a WRD and a LOPAP system conducted in a similar atmospheric environment in China ( $\mathrm{Su}, 2008)$ :

$\mathrm{HONO}_{\mathrm{LOPAP}}=0.833 \times \mathrm{HONO}_{\mathrm{WRD}}-0.17$.

It should be noted that the data set corrected by this formula is expected to underestimate the HONO concentration because the absorption solution deployed by $\mathrm{Su}$ (2008) was $\mathrm{Na}_{2} \mathrm{CO}_{3}$, which can induce additional interference in WRD (interference 2 and part of interference 1). Given that we probably underestimated the HONO concentrations and overestimated the $\mathrm{NO}_{2}$ concentrations (Xu et al., 2013), the values of $\mathrm{HONO} / \mathrm{NO}_{2}$ and $\mathrm{HONO} / \mathrm{NO}_{\mathrm{x}}$ calculated in Sect. 3 are actually lower limits for these ratios.

Several studies (Appel et al., 1990; Muller et al., 1999; Genfa et al., 2003) have demonstrated that the overestimation of HONO concentrations measured by WRD mainly occur during daytime, so we used only nighttime data (except in the case of 10 June, when the solar radiation was significantly decreased to a very low level (Ding et al., 2013b) in Sects. 3.2 and 3.3.

\subsection{Calculation of the nocturnal HONO lifetime}

Generally the nocturnal boundary layer is low and stable, the observed plumes during the nighttime were assumed to always be transported inside the planetary boundary layer (PBL) and probably make contact with the ground surface. In this case, there are three major pathways for the loss of HONO during nighttime, including deposition on ground surfaces (Path-A), heterogeneous loss on aerosol surfaces (Path-B) and reaction with the $\mathrm{OH}$ radical (Path-C) (Li et al., 2012). For Path-A, the HONO lifetime $\left(T_{\mathrm{a}}\right)$ is given by

$T_{\mathrm{a}}=\frac{1}{k_{\mathrm{a}}}=\frac{H}{V_{\mathrm{HONO}}}$,

where $H$ is the mixing height (assumed as $100 \mathrm{~m}$ ) and $V_{\mathrm{HONO}}$ is the dry deposition velocity of $\mathrm{HONO}$, assumed to be equal to $0.8 \mathrm{~cm} \mathrm{~s}^{-1}$ (Li et al., 2012). For the loss Path-B, the corresponding lifetime $\left(T_{\mathrm{b}}\right)$ can be written as

$T_{\mathrm{b}}=\frac{1}{k_{\mathrm{b}}}=\frac{1}{\frac{1}{4} \times \gamma_{\mathrm{HONO}} S_{\text {aerosol }} \times \overline{v_{\mathrm{HONO}}}}$.

There is no modern literature reporting the HONO uptake coefficient on aerosols, but an uptake coefficient of HONO on the ground ranging from $10^{-5}$ to $10^{-4}$ was reported in recent studies (VandenBoer et al., 2013; Donaldson et al., 2013). Considering the lower surface area and $\mathrm{pH}$ of aerosols (Su et al., 2011), the uptake coefficient of HONO on aerosols may be less and was estimated as $10^{-5}$ or less. $S_{\text {aerosol }}$ is the aerosol surface during the observation with a mean value of about $1.5 \times 10^{3} \mu \mathrm{m}^{2} \mathrm{~cm}^{-3}$ calculated from the particle size 

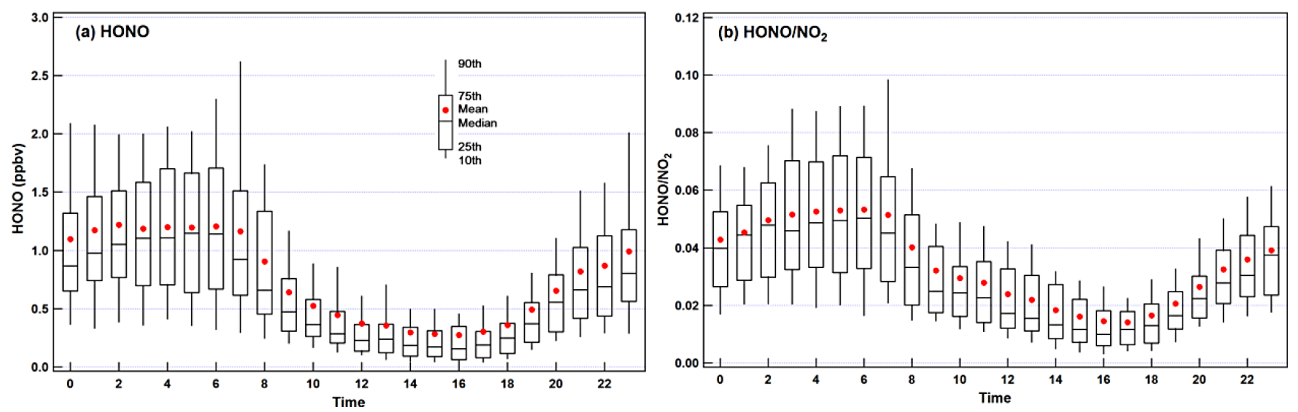

Figure 2. Whisker plot of diurnal variation of (a) HONO and (b) $\mathrm{HONO} / \mathrm{NO}_{2}$ at the SORPES station during April-June 2012.

distribution, and $\overline{v_{\mathrm{HONO}}}$ is the mean molecular velocity of HONO (about $380 \mathrm{~m} \mathrm{~s}^{-1}$ ). For the loss Path-C, the lifetime $\left(T_{\mathrm{c}}\right)$ is equal to

$T_{\mathrm{c}}=\frac{1}{k_{\mathrm{c}}}=\frac{1}{k_{\mathrm{HONO}+\mathrm{OH}} \times \mathrm{OH}}$.

The $\mathrm{OH}$ concentration was estimated as $10^{6} \mathrm{~cm}^{-3}$ (Hofzumahaus et al., 2009). $k_{\mathrm{HONO}+\mathrm{OH}}$ is the reaction rate of $\mathrm{HONO}$ and $\mathrm{OH}$. The value of $5.0 \times 10^{-12} \mathrm{~cm}^{3} \mathrm{~s}^{-1}$ at $298 \mathrm{~K}$ (Sander et al., 2006) was used. In these conditions, the overall lifetime, $t$ is obtained from the following formula:

$\frac{1}{t}=\frac{1}{T_{\mathrm{a}}}+\frac{1}{T_{\mathrm{b}}}+\frac{1}{T_{\mathrm{c}}}$

The lifetime of HONO was calculated to be about $3.3 \mathrm{~h}$. That means about $8-9 \mathrm{~h}$ are needed for the emitted HONO to be consumed within the nocturnal PBL.

\subsection{Tracer of biomass burning plumes}

Most BB tracers are organic compounds (Simoneit, 2002; Andreae and Merlet, 2001), which were not measured during this campaign. Carbon monoxide (CO) in the gas phase (Andreae and Merlet, 2001) and potassium ions $\left(\mathrm{K}^{+}\right)$in the aerosol phase (Andreae, 1983; Ma et al., 2003; Reid et al., 2005; Li et al., 2007) are well recognized inorganic tracers of BB. In this study, the observation site is located in the YRD, one of the most developed, and most polluted, regions in China (Ding et al., 2013c). Many CO sources other than BB, such as industry and traffic, can contribute significantly to the $\mathrm{CO}$ loading, even during the BB season. Otherwise, there are no other significant sources of $\mathrm{K}^{+}$in this region. Therefore, $\mathrm{K}^{+}$is a suitable tracer of $\mathrm{BB}$ for regions with heavy air pollution. In this study, the samples with $\mathrm{K}^{+}$concentrations higher than $2 \mu \mathrm{g} \mathrm{m}^{-3}$ and a ratio of $\mathrm{K}^{+}$to $\mathrm{PM}_{2.5}$ larger than 0.02 were defined as BB samples (203 samples). The samples with $\mathrm{K}^{+}$concentrations lower than $2 \mu \mathrm{g} \mathrm{m}^{-3}$ and a ratio of $\mathrm{K}^{+}$to $\mathrm{PM}_{2.5}$ smaller than 0.02 were categorized as nonBB samples (1122 samples). The defined samples, including $\mathrm{BB}$ and non-BB, account for $82.4 \%$ of the total. The other undefined samples account for $17.6 \%$.

\section{Results and discussion}

\subsection{Observation overview}

Figure 1 shows the temporal variations of concentrations of $\mathrm{HONO}, \mathrm{NO}_{2}, \mathrm{PM}_{2.5}$ mass and $\mathrm{K}^{+}$observed at the Xianlin SORPES central site during the time period of April-June 2012. The average concentration of HONO was $0.76 \pm 0.79 \mathrm{ppbv}$, which was lower than the concentrations measured at a polluted rural site in the Pearl River delta region (Su et al., 2008) and an urban site in Shanghai (Wang et al., 2013), but much higher than those measured in $\mathrm{Eu}-$ rope (Acker and Möller, 2007). Both HONO concentrations (Fig. 2a) and ratios of $\mathrm{HONO}$ to $\mathrm{NO}_{2}\left(\mathrm{HONO} / \mathrm{NO}_{2}\right)$ (Fig. 2b) exhibited distinct diurnal cycles, with a diurnal maximum during night/early morning and a minimum around noon.

During the campaign, and especially from late May to early June, several BB episodes were observed and revealed by elevated concentrations of $\mathrm{PM}_{2.5}$ (up to $426 \mu \mathrm{g} \mathrm{m}^{-3}$ ) and $\mathrm{K}^{+}$(up to $22 \mu \mathrm{g} \mathrm{m}^{-3}$ ) (Fig. 1) (Ding et al., 2013b; Ding et al., 2013c). HONO concentrations were also enhanced during the BB episodes. In order to investigate the relation between $\mathrm{BB}$ and HONO chemistry, we compared the HONO concentrations, $\mathrm{HONO} / \mathrm{NO}_{2}$ ratios and $\mathrm{HONO} / \mathrm{NO}_{\mathrm{x}}$ ratios between the $\mathrm{BB}$ and non-BB periods. On average, all three parameters were significantly enhanced during BB periods compared to non-BB periods (Fig. 3d, e, f). HONO concentrations increased by $156 \%(1.56 \pm 1.43 \mathrm{ppbv}$ vs. $0.61 \pm 0.54 \mathrm{ppbv}, p<0.01) ; \mathrm{HONO} / \mathrm{NO}_{2}$ ratios increased by $137 \%(0.066 \pm 0.043$ vs. $0.028 \pm 0.020, p<0.01)$; and $\mathrm{HONO} / \mathrm{NO}_{\mathrm{x}}$ ratios increased by $134 \% \quad(0.055 \pm 0.031$ vs. $0.023 \pm 0.016, p<0.01)$. These results indicate a positive impact of BB plumes on the ambient mixing ratio of HONO.

The enhanced HONO production in BB plumes would impact the atmospheric oxidation capacity, and influence the formation of secondary aerosols ( $\mathrm{Li}$ et al., 2010; Gonçalves et al., 2012; Elshorbany et al., 2014). In this study, the average values of HONO to $\mathrm{NO}_{\mathrm{x}}$ ratios $(0.028 \pm 0.021)$, especially during the $\mathrm{BB}$ periods $(0.062 \pm 0.031)$ (see Fig. $3 f$ ) were considerably higher than 0.02 , the assumed global aver- 

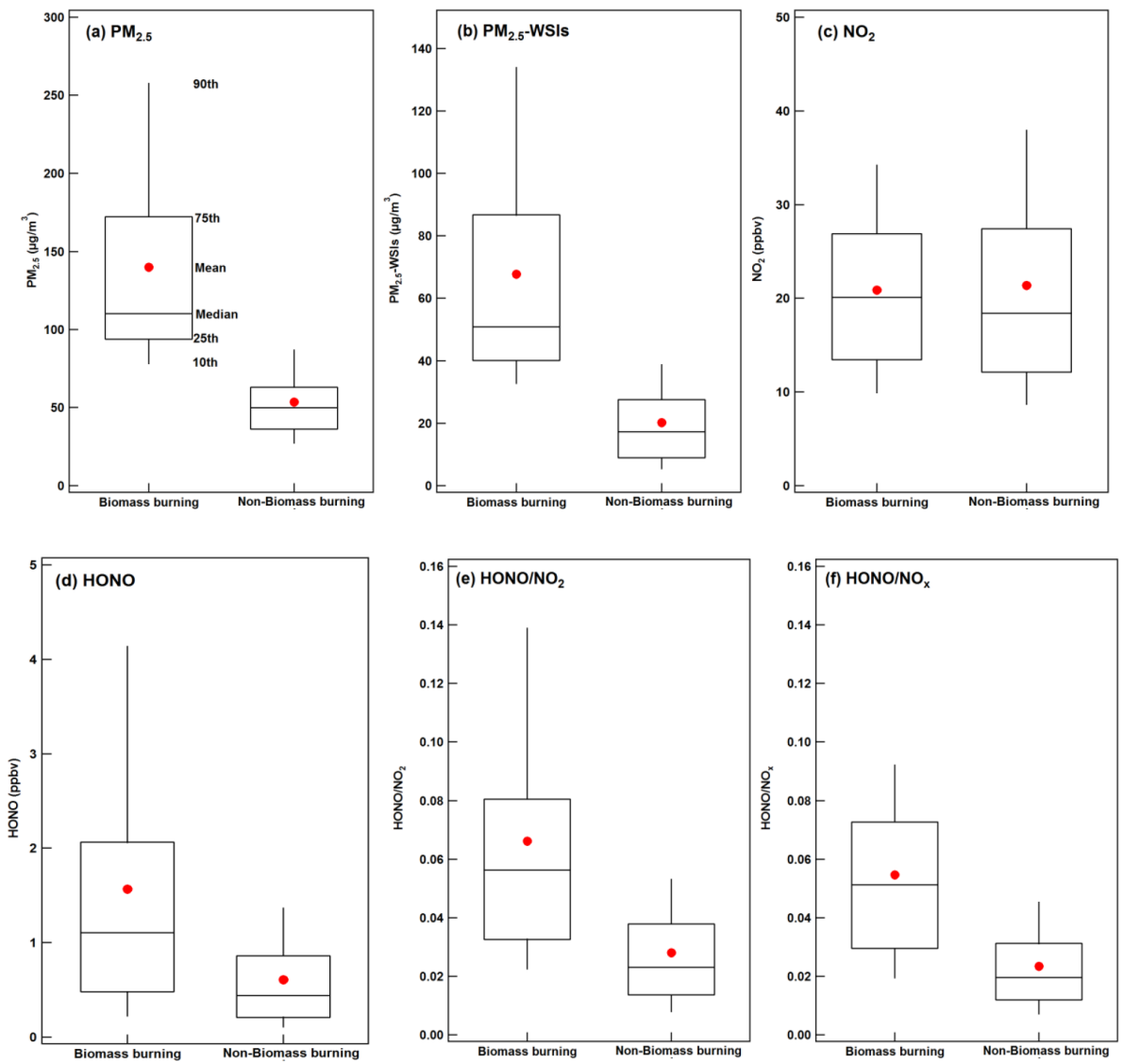

Figure 3. Comparisons between BB periods (203 samples) and non-BB periods (1122 samples) of (a) $\mathrm{PM}_{2.5}$ concentrations, (b) concentrations of organic matter in $\mathrm{PM}_{2.5}$ (estimated by $\mathrm{PM}_{2.5}$-WSIs), (c) $\mathrm{NO}_{2}$ concentrations, (d) $\mathrm{HONO}$ concentrations, (e) $\mathrm{HONO}$ to $\mathrm{NO}_{2}$ ratio and (f) $\mathrm{HONO}$ to $\mathrm{NO}_{\mathrm{x}}$ ratio. There are statistically significant differences for all the data pairs $(p \ll 0.01)$ except $\mathrm{NO}_{2}(p=0.51)$.
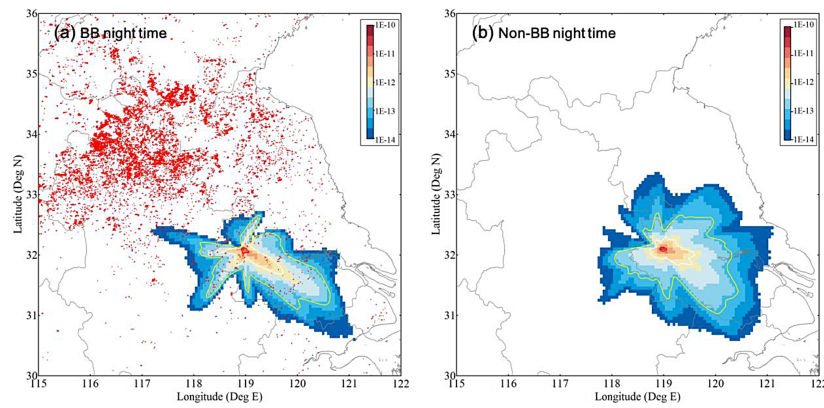

Figure 4. Map of $8 \mathrm{~h}$ Lagrangian backward retroplume $(100 \mathrm{~m}$ footprint layer) for (a) BB air masses (defined as $\mathrm{K}^{+}>2 \mu \mathrm{g} \mathrm{m}^{-3}$ and $\mathrm{K}^{+} / \mathrm{PM}>2 \%$ ) during nighttime, and (b) non-BB air masses (defined as $\mathrm{K}^{+}<2 \mu \mathrm{g} \mathrm{m}^{-3}$ and $\mathrm{K}^{+} / \mathrm{PM}<2 \%$ ) and active fire (pink dots) during 1-15 June 2012 (data obtained from FIRMS MODIS Fire Archive).

aged value (Elshorbany et al., 2012; Elshorbany et al., 2014), suggesting a potentially more important role for $\mathrm{HONO}$ chemistry in the YRD, especially during the BB season.

\subsection{Influence of BB on HONO formation}

\subsubsection{Contribution of direct emission}

Several laboratory studies have demonstrated BB as an effective HONO source via direct emissions (Burling et al., 2010; Veres et al., 2010), so HONO might play an important role in the atmospheric chemistry over BB source regions. However, HONO is easily consumed by chemical sinks during its atmospheric transport (the estimated lifetime was about $3.3 \mathrm{~h}$ in the nighttime, and emitted HONO can be consumed in about 8 hours, see Sect. 2.4). In this study, the main BB source area is located in the northern part of Anhui province, several hundred kilometers from the SORPES station (Fig. 4). As shown in Fig. 4a, in addition to some individual fire points distributed in the $8 \mathrm{~h}$ backward retroplume, the air masses from the major source regions cannot influence the SORPES station in $8 \mathrm{~h}$ transport, suggesting that direct emission from BB may have an influence on the observed enhancement of the HONO but should not be the major contributor. The correlations of $\mathrm{HONO}$ with $\mathrm{K}^{+}$(BB tracer) and $\mathrm{NO}_{2}$ for the nighttime BB samples were illustrated in Figs. 5 


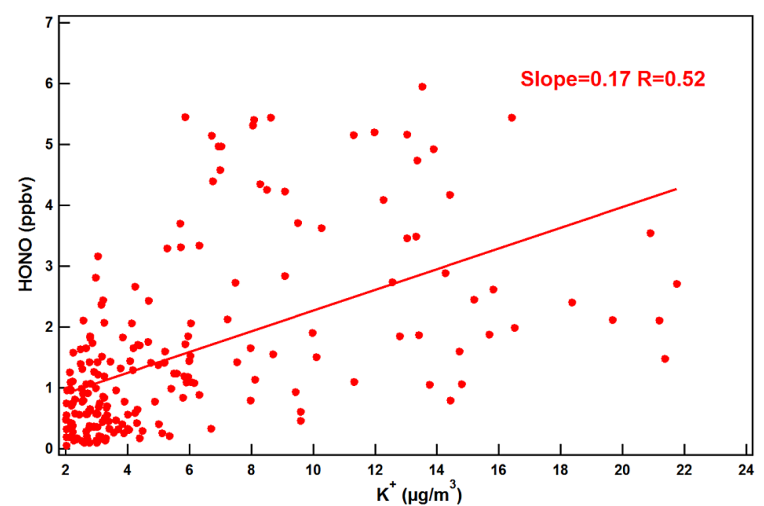

Figure 5. Scatter plot between the HONO and potassium concentration during BB periods.

and 10 . The results showed that the HONO was positively correlated to both $\mathrm{K}^{+}$and $\mathrm{NO}_{2}$, but the correlation efficiency $(R)$ for $\mathrm{HONO}$ and $\mathrm{NO}_{2}$ was higher than that for $\mathrm{HONO}$ and $\mathrm{K}^{+}$. These results indicate that despite of some contribution from direction emission, the secondary production of $\mathrm{HONO}$ should play the key role.

As few publications reported the emission factors of both $\mathrm{K}^{+}$and HONO from the burning of wheat straw, to estimate the contribution of $\mathrm{BB}$ direct emission to $\mathrm{HONO}$ here we first calculated the contribution of $\mathrm{BB}$ emission to observed $\mathrm{CO}$ concentrations. The ratio of emission factors of $\mathrm{K}^{+}$and $\mathrm{CO}$ was assumed to be identical for the BB events observed during this campaign. Here we took the minimum molar ratio of non-background $\mathrm{CO}$ to $\mathrm{K}^{+}$for nighttime $\mathrm{BB}$ samples (the value was 67) as the ratio of the emission factors of these two species because of the additional strong $\mathrm{CO}$ sources other than BB emission in the YRD. The background concentrations of CO around the SORPES station were estimated as the intercept of the linear regression fit for the whole samples of $\mathrm{CO}$ and $\mathrm{NO}_{\mathrm{y}}$ during the campaign (the value was $480 \mathrm{ppb}$, figure not shown) (Wang et al., 2004). In this case, the CO concentration contributed from BB emission was calculated to be $260 \pm 189$ ppbv.

We then estimated the contribution of BB emission to observed HONO concentrations by taking account of the emission ratio of HONO to $\mathrm{CO}$ from the burning of wheat straw and the loss of emitted HONO during transport. Noting that the deposition of $\mathrm{CO}$ and $\mathrm{K}^{+}$in fine particles was slow, their losses during transport were assumed to be negligible. The averaged emission ratio of $\mathrm{HONO}$ to $\mathrm{CO}$ from the burning of wheat straw was taken as 0.0027 (Stockwell et al., 2014). The loss of HONO should be related to the transport time of BB plumes. However, the transport time was difficult to calculate as the exact source region (fire point on the map, Fig. 4) for each BB episode cannot be identified. Some episodes may be influenced by several source regions on the transport pathway, and the exact time and duration of the fires cannot be identified with the satellite fire count data. However, given

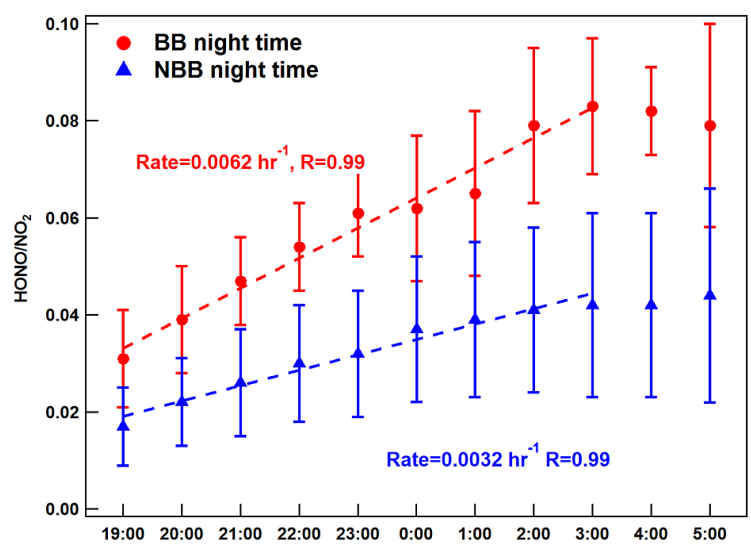

Figure 6. Ratios of $\mathrm{HONO}$ to $\mathrm{NO}_{2}$ for nighttime samples of $\mathrm{BB}$ (except for the 10 June case) and non-BB plumes. The change rates were calculated from 19:00 to 02:59. Error bars are the standard deviations.

that there were few fire points very close to the SORPES station (Fig. 4), and the air plumes of several episodes, such as 9-11 June and 12-13 June, have been demonstrated as being transported for several days before arriving at the station (Fig. 9d and e in Ding et al., 2013c), we therefore used $3.3 \mathrm{~h}$ (HONO nighttime lifetime, see Sect. 2.4) as the mean transport time, which is actually underestimated for most BB episodes to estimate HONO loss during transportation. In which case, although there may be large uncertainties, here our best estimate of the HONO contribution from direct emission of BB was $0.27 \pm 0.19$ ppbv, which accounted for $17 \pm 12 \%$ of the observed HONO concentrations. That means more than $80 \%$ of the observed nighttime HONO during $\mathrm{BB}$ periods was secondarily formed.

\subsubsection{Heterogeneous conversion and the possible influence of the ground surface}

The reaction of $\mathrm{NO}$ and $\mathrm{OH}$ was one major source of daytime HONO, but its contribution to nighttime HONO is negligible due to the limitation of nighttime $\mathrm{OH}$ concentration. Therefore, over $80 \%$ of the observed HONO in the nighttime BB plumes, which was secondary formed, should be produced from the heterogeneous conversation of $\mathrm{NO}_{2}$. In which case, the enhancement of HONO during BB periods should be ascribed to either the increase in $\mathrm{NO}_{2}$ concentrations or increased $\mathrm{NO}_{2}$ to $\mathrm{HONO}$ conversion potentials. As shown in Figs. 1 and 3c, the concentration levels of $\mathrm{NO}_{2}$ were comparable during the $\mathrm{BB}$ and non-BB periods $(p=0.51)$, so the higher HONO level during $\mathrm{BB}$ periods was probably due in large part to a higher $\mathrm{NO}_{2}$ conversion potential $\left(\mathrm{HONO} / \mathrm{NO}_{2}\right.$ ratio).

To further verify this point, in Fig. 6 we presented the changes of $\mathrm{HONO}$ to $\mathrm{NO}_{2}$ ratios during nighttime for both $\mathrm{BB}$ and non-BB plumes. The $\mathrm{NO}_{2}$-to-HONO conversion rate $\left(C_{\mathrm{HONO}}\right)$, which estimated by change rates of $\mathrm{HONO} / \mathrm{NO}_{2}$ 
ratios along the time (the slopes in Fig. 6, 19:00-03:00), in BB plumes almost two times higher than that in non-BB plumes $\left(0.0062 \mathrm{hr}^{-1}\right.$ vs. $\left.0.0032 \mathrm{hr}^{-1}\right)$, further suggesting a higher $\mathrm{NO}_{2}$ conversion potential to produce $\mathrm{HONO}$ in $\mathrm{BB}$ plumes than that in non-BB plumes.

Both ground and aerosols are effective surfaces for converting $\mathrm{NO}_{2}$ to $\mathrm{HONO}$. Here, to estimate the possible role of the ground surface in the enhancement of HONO concentrations, we conducted backward Lagrangian dispersion modeling for the air masses arriving at the SORPES station using the HYSPLIT model, following the method developed by Ding et al. (2013a). Considering that the nighttime HONO lifetime was estimated to be about $3.3 \mathrm{~h}$, we ran the models for an $8 \mathrm{~h}$ backward period, during which the emitted HONO from BB could possibly be consumed. Figure $4 \mathrm{a}$ and $\mathrm{b}$ presents the "footprint" retroplumes, which represented the distribution of probability or residence time of the simulated air masses in their last $8 \mathrm{~h}$ transport time prior to arrival at the measurement site (Ding et al., 2013a). The residence time was calculated to be $10 \%$ lower for $\mathrm{BB}$ air masses than for non-BB air masses, suggesting that the aerosol surface rather than the ground surface was the major contributor to the observed enhancement of HONO concentrations and $\mathrm{HONO} / \mathrm{NO}_{2}$ ratios during $\mathrm{BB}$ periods. It should be noted here that we cannot totally get rid of the influence of the ground surface as the exact role of varied land use and land cover in HONO chemistry was not clear. But the results tend to support the view that heterogeneous reaction of $\mathrm{NO}_{2}$ on the surface of $\mathrm{BB}$ aerosols was the major contributor to the observed increase of $\mathrm{HONO}$ concentration during $\mathrm{BB}$ periods.

\subsubsection{Role of BB aerosols in HONO chemistry}

The surface area and chemical nature of aerosol particles are the two dominating factors that influence the heterogeneous conversion of $\mathrm{NO}_{2}$ to produce HONO. In this study, the enhanced aerosol particle loadings associated with the BB plumes (Figs. 1 and 3a), providing large aerosol surface areas (Fig. 7a), should aid the conversion of $\mathrm{NO}_{2}$ to $\mathrm{HONO}$. Besides particle mass concentration, the particle specific surface area related to the particle size distribution and morphology also influences the total particle surface area concentration. In Fig. 7a, we present the relationship between the particle surface area and particle mass concentration $\left(\mathrm{PM}_{2.5}\right)$ for both the BB and non-BB samples. The slope of the data pairs for $\mathrm{BB}$ samples was almost twice as that of non-BB aerosols, suggesting a much higher specific surface area for $\mathrm{BB}$ aerosols than that for non-BB aerosols. To further verify this point and find out the causes, we selected the samples with the $\mathrm{PM}_{2.5}$ mass in the overlap concentration range 100$150 \mu \mathrm{g} \mathrm{m}^{-3}$ during both BB and non-BB periods (Fig. 7a and b), and compared their surface area concentrations calculated by the size distribution (Fig. 7c). The results showed an evidently larger surface area concentration for BB aerosols com-
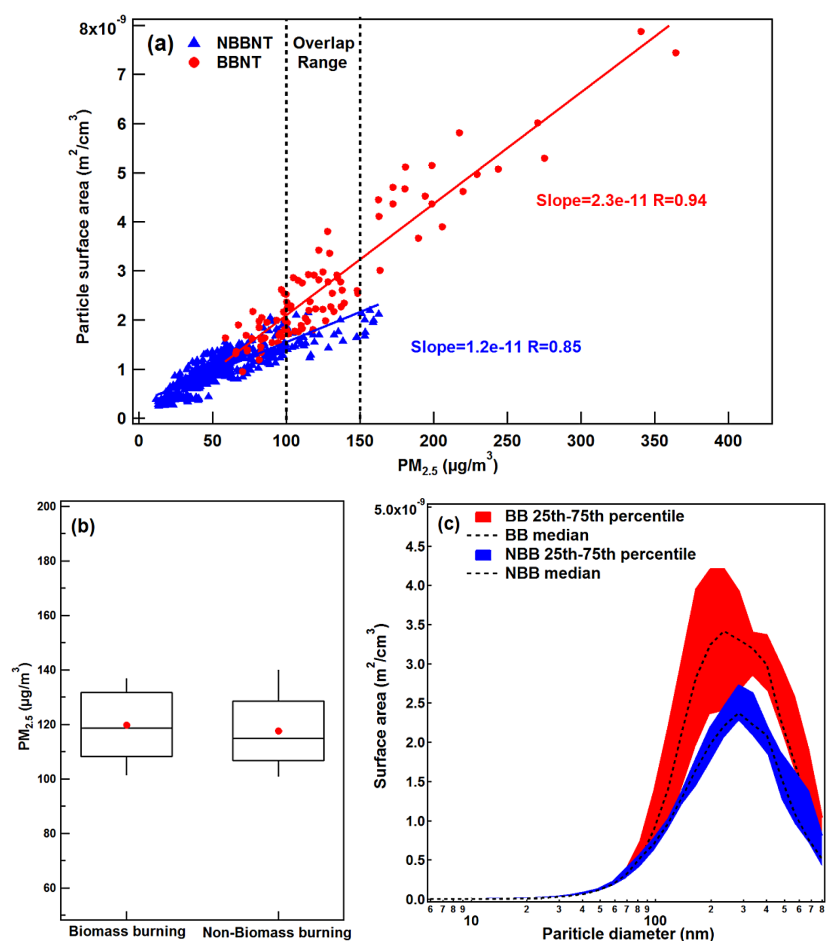

Figure 7. (a) Scatter plot between the particle surface area and $\mathrm{PM}_{2.5}$ for nighttime samples during $\mathrm{BB}$ and non-BB periods, (b) whisker plot of $\mathrm{PM}_{2.5}$ in the selected mass concentration range (100-150 $\mathrm{g} \mathrm{m}^{-3}$, shown in Fig. 7a) during BB (51 samples) and non-BB periods (27 samples), and (c) particle surface area size distributions for the same subsets of data.

pared with non-BB aerosols. These results clearly suggest that $\mathrm{BB}$ aerosols have a larger specific surface area than non$\mathrm{BB}$ aerosols, which is caused by a much higher number of accumulation mode particles, and favor $\mathrm{NO}_{2}$ to $\mathrm{HONO}$ conversion at similar levels of the PM mass concentration. To further investigate the influence of BB aerosols on the particle specific surface area, we plotted the ratios of particle surface area to $\mathrm{PM}_{2.5}$ against the abundance of potassium in $\mathrm{PM}_{2.5}$ (Fig. 8) during BB periods. The result showed a positively linear correlation between the two metrics, suggesting a strong enhancement of BB aerosols on the particle specific area concentrations. Besides the surface area concentrations, the chemical nature of aerosols, which control the $\mathrm{NO}_{2}$ conversion efficiency, is also a candidate influencing the transformation of $\mathrm{NO}_{2}$ to $\mathrm{HONO}$.

The $\mathrm{NO}_{2}$ conversion efficiency refers to the ability of the interface to convert $\mathrm{NO}_{2}$ to $\mathrm{HONO}$. In the ambient air, both aerosol and ground surface contribute to the $\mathrm{HONO} / \mathrm{NO}_{2}$ ratio. Therefore, the $\mathrm{NO}_{2}$ conversion efficiency can be represented by $\left(\mathrm{HONO} / \mathrm{NO}_{2} /\right.$ (particle surface area + ground surface area) when the $\mathrm{NO}_{2}$ and $\mathrm{HONO}$ reach a steady state (02:00-05:59, see Fig. 6). Here, we assume the related ground surface areas for each $\mathrm{BB}$ or non-BB sample are the same. In which case, the ratios of $\left(\mathrm{HONO} / \mathrm{NO}_{2}\right) /($ ground 


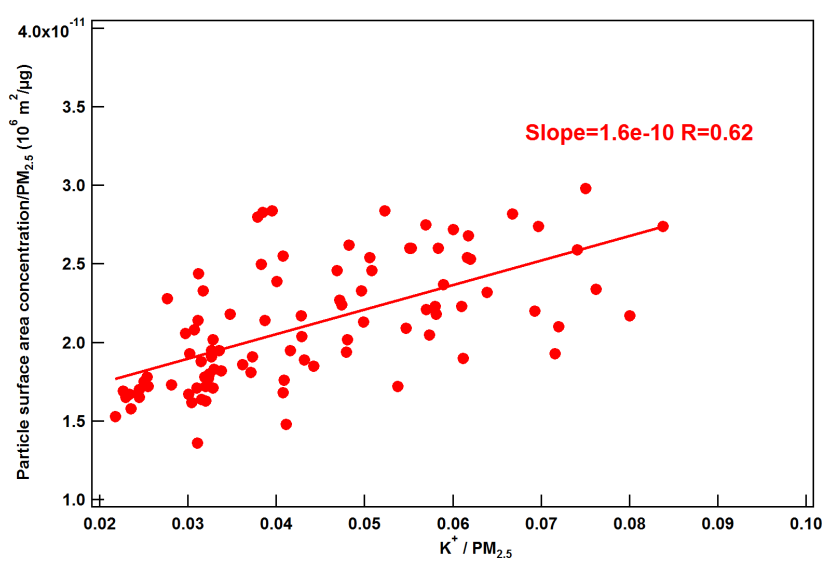

Figure 8. Scatter plot between the ratio of particle surface area to $\mathrm{PM}_{2.5}$ and the abundance of potassium in $\mathrm{PM}_{2.5}$ for nighttime samples during $\mathrm{BB}$ period.

surface + aerosol surface) can only be compared when the aerosol surface areas of $\mathrm{BB}$ and non-BB aerosols are the same. Therefore, we selected the samples at $\mathrm{HONO}$ and $\mathrm{NO}_{2}$ steady state with the surface area concentrations in the overlapped range $1.5-2.2 \times 10^{-9} \mathrm{~m}^{2} \mathrm{~cm}^{-3}$, and compared the ratios of $\left(\mathrm{HONO} / \mathrm{NO}_{2}\right) /($ aerosol surface $)$ instead to the comparison of $\left(\mathrm{HONO} / \mathrm{NO}_{2}\right) /($ ground surface + aerosol surface). As shown in Fig. 9, the values of this ratio were $67 \%$ higher for BB samples than those for non-BB samples, further suggesting the $\mathrm{NO}_{2}$ conversion efficiency of $\mathrm{BB}$ aerosols was higher than that of non-BB aerosols.

In summary, the elevated HONO formation observed in BB plumes was caused by the combined effects of enhanced particle loadings, higher specific aerosol surface areas, and more efficient conversion of $\mathrm{NO}_{2}$ to $\mathrm{HONO}$ on particle surfaces. It is well known that high particle loadings associated with BB are caused by both primary particle emissions and secondary aerosol formation during atmospheric transport (Andreae and Merlet, 2001; Li et al., 2003; Capes et al., 2008). Large aerosol specific surface areas are probably due to the extremely high number concentrations of accumulation mode particles during BB (Janhäll et al., 2010), and possibly the irregular shape of soot particles (Dobbins and Megaridis, 1987; Cai et al., 1993), which is one major product of $\mathrm{BB}$. The higher $\mathrm{NO}_{2}$ to $\mathrm{HONO}$ conversion efficiency on particle surfaces in $\mathrm{BB}$ plumes compared with non-BB air is a complex issue. One possible reason is the high abundance of organic (e.g., humic-like substances) and soot particles (Reid et al., 2005), which are high-performance media for converting $\mathrm{NO}_{2}$ to HONO. This is supported by the much higher concentrations of organics and black carbon, estimated as the differences of $\mathrm{PM}_{2.5}$ and the water-soluble ions, in BB periods compared to those in non-BB periods (see Fig. 3b).

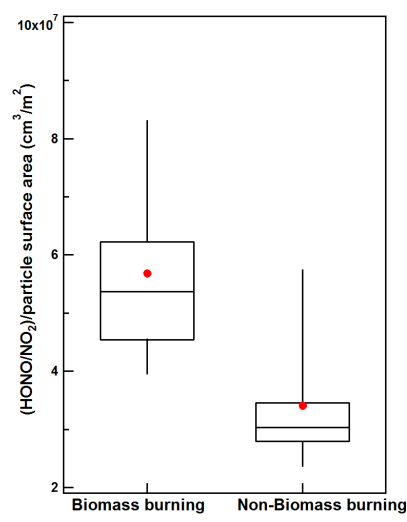

Figure 9. Whisker plot of the ratios between $\mathrm{HONO} / \mathrm{NO}_{2}$ and particle surface area concentration for the samples at steady state (02:00-05:59) with the particle surface area in the range of 1.5$2.2 \times 10^{-9} \mathrm{~m}^{2} \mathrm{~cm}^{-3}$ during the BB (14 samples) and non-BB periods (21 samples).

\subsection{Influence of mixed plumes of biomass burning and fossil fuel emissions on HONO chemistry}

An intense BB episode mixed with FF emissions that significantly influenced everyday weather was observed on 10 June 2012 (from 18:00 on 9 June to 05:00 on 11 June) (Ding et al., 2013b). Interestingly, the highest mixing ratios of HONO, exceeding 5 ppbv, occurred during this episode (Fig. 1). The solar radiation intensity was significantly decreased in the daytime of this episode due to the extremely high particle loading (see Fig. 3 in Ding et al., 2013b), and HONO concentrations during the daytime were at a similar level to those during the nighttime. Again, we investigated the relation between HONO and potassium. The result showed no correlation (slope $=-0.08, R=0.24$, figure not shown), suggesting that the enhanced HONO concentrations during the case of 10 June were secondarily produced. Although a high particle loading should be a contributor to the high HONO levels, it was unlikely to be the most predominant factor because the $\mathrm{PM}$ concentrations during this event were comparable to the peak concentrations during the other BB episodes (Fig. 1). Another possible reason is that the plumes on 10 June were more aged than the other BB plumes, which would enhance the $\mathrm{HONO}$ production with a longer $\mathrm{NO}_{2}$ contact time with the aerosol and ground surface. However, as shown in Fig. 6, $\mathrm{HONO}$ and $\mathrm{NO}_{2}$ can reach a steady state in 8 hours. The steady values of $\mathrm{HONO} / \mathrm{NO}_{2}$ ratios were $0.083 \pm 0.014$ (the value for 03:00) for other BB plumes, which were still much lower than those in the 10 June case $(0.17 \pm 0.046)$, suggesting some other factors other than the plume age enhanced the HONO concentrations during 10 June.

Figure 10 shows the scatter plot between $\mathrm{HONO}$ and $\mathrm{NO}_{2}$ concentrations during the BB periods. The data set was separated into two groups: the first $5 \mathrm{~h}$ of the 10 June case (red squares, 18:00-22:00 on 9 June) combined with other BB 


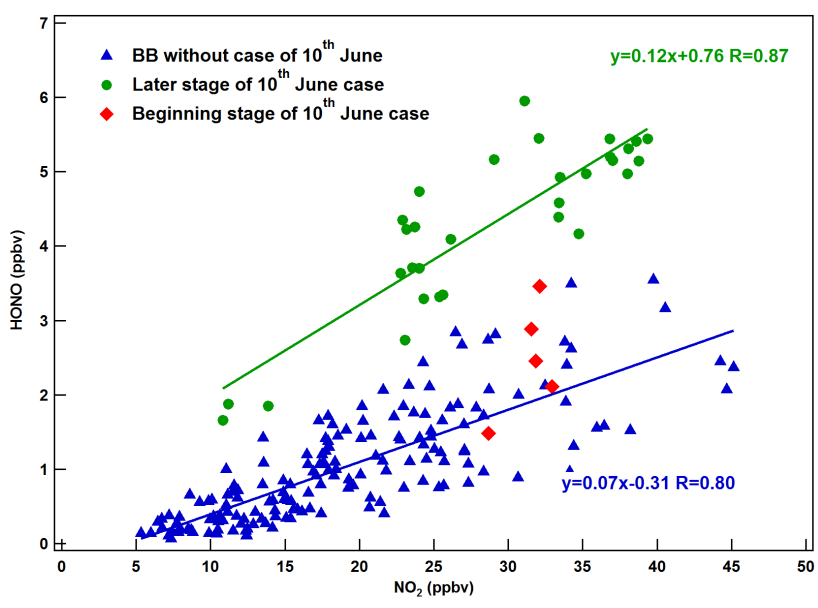

Figure 10. Scatter plot between $\mathrm{HONO}$ and $\mathrm{NO}_{2}$ concentration during the BB periods (without the case of 10 June, blue solid squares), the beginning (red solid diamonds) and latter (green dots) state of the 10 June episode.

episodes (blue squares) and the later stage of the 10 June case (green circle dots). Both groups revealed a strong relation between $\mathrm{HONO}$ and $\mathrm{NO}_{2}$ with a correlation coefficient higher than 0.8 . The slope of the regression of the latter stage of the 10 June case was almost twice that of the other group ( 0.12 vs. 0.07 ), indicating a higher $\mathrm{NO}_{2}$ to $\mathrm{HONO}$ conversion potential of the aerosols in the later stage of the 10 June case compared with other BB episodes.

To further verify this point and exclude the influence of particle loading, samples with $\mathrm{PM}_{2.5}$ concentrations in the range $190-300 \mathrm{\mu g} \mathrm{m}^{-3}$ (the overlapping parts) were selected from both groups. Although the selected samples had similar PM concentration levels (Fig. 11a), the $\mathrm{HONO} / \mathrm{NO}_{2}$ ratios (Fig. 11b) and ratios between $\mathrm{HONO} / \mathrm{NO}_{2}$ and $\mathrm{PM}_{2.5}$ (Fig. 11c) were much higher on the 10 June than those during the other BB episodes, indicating a higher potential for the aerosols on the 10 June to convert $\mathrm{NO}_{2}$ to HONO. It should be noted that particle surface area data were not available for the 10 June case because the extremely high particle loading influenced the sample inlet of the differential mobility particle sizer (DMPS). The exact contributors to the enhancement of $\mathrm{NO}_{2}$ conversion potentials, which was either higher specific aerosol surface areas or stronger conversion efficiency, are therefore not clear.

Our previous study demonstrated that the episode on the 10 June was caused not only by BB but a mixture of intense BB and anthropogenic FF emissions (Ding et al., 2013b). As shown in Fig. 12, the $\mathrm{SO}_{2}$ concentration was low at the beginning of this episode and then gradually increased, suggesting the mixing of anthropogenic pollution rich in $\mathrm{SO}_{2}$ with the $\mathrm{BB}$ particles several hours after the invasion of the $\mathrm{BB}$ plume. This is why the chemical features $\left(\mathrm{HONO} / \mathrm{NO}_{2}\right)$ in the plume at the beginning stage of the 10 June case was
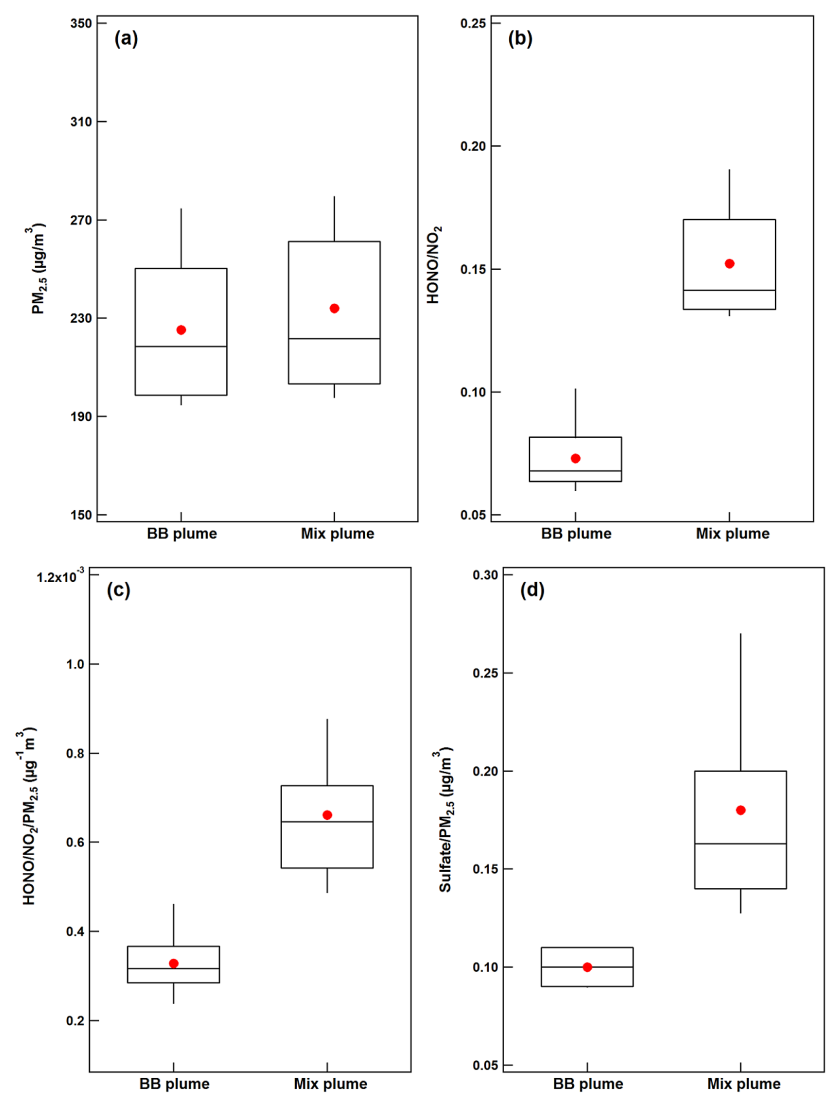

Figure 11. Whisker plots of (a) $\mathrm{PM}_{2.5}$ mass, (b) ratios of HONO to $\mathrm{NO}_{2}$, (c) ratios of $\mathrm{HONO} / \mathrm{NO}_{2}$ to $\mathrm{PM}_{2.5}$ mass, (d) ratios of sulfate to $\mathrm{PM}_{2.5}$, in the selected $\mathrm{PM}_{2.5}$ mass concentration range (190$300 \mu \mathrm{g} \mathrm{m}^{-3}$ ) in the BB plume (10 samples) and the mixed plume (27 samples).

similar to that in other BB episodes, yet very different from the later stage of the 10 June case (Fig. 10).

The mix of BB plumes and FF emissions will promote the formation of secondary aerosols (e.g. sulfate and secondary organic aerosols (SOA)) on BB particles, and thus modify their morphology and surface chemical nature $(\mathrm{Li}$ et al., 2003; Capes et al., 2008). As shown in Fig. 11d, the abundance of sulfate in $\mathrm{PM}_{2.5}$ was significantly enhanced in the 10 June case compared with other BB episodes. This coincided with the high $\mathrm{NO}_{2}$ to $\mathrm{HONO}$ conversion efficiency (Fig. 11c), indicating a promotion of secondary aerosol formation on $\mathrm{BB}$ particles in the mixed plumes to produce HONO. To further verify this point, we plotted the nighttime HONO concentration against the sulfate concentration on 10 June (Fig. 13), noting that the daytime HONO chemistry is completely out of the range of the nighttime correlations. The result shows a very good correlation between the two compounds $(R=0.79)$, further suggesting the promotion of secondary aerosol formation on BB particles to HONO formation. 


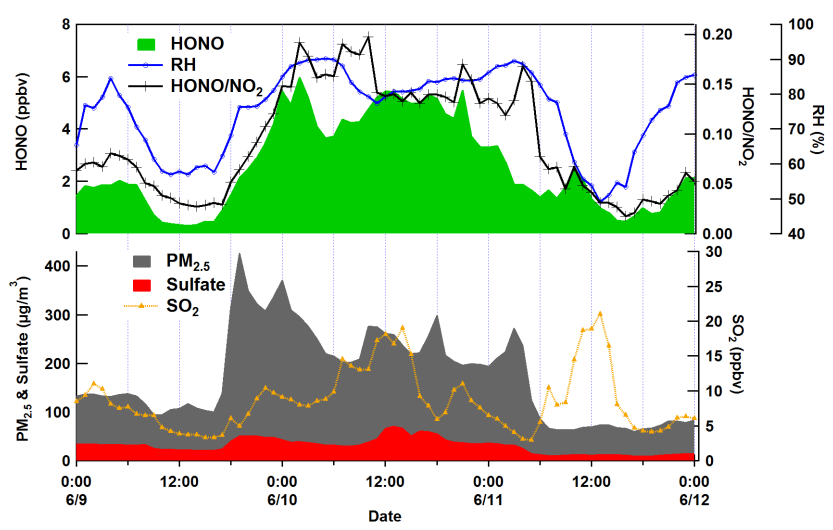

Figure 12. Temporal variations of $\mathrm{HONO}, \mathrm{HONO} / \mathrm{NO}_{2}$ ratios, $\mathrm{RH}$, $\mathrm{PM}_{2.5}$, sulfate in $\mathrm{PM}_{2.5}$ and $\mathrm{SO}_{2}$ during 9-11 June 2012 at the SORPES station.

As discussed above, the specific surface area and chemical nature of aerosol particles are the key factors in determining their potential to convert $\mathrm{NO}_{2}$ to $\mathrm{HONO}$. Therefore, changes in the morphology and size distribution caused by secondary aerosol formation may have enhanced the specific surface area and led to increased HONO production in the mixed plumes. Besides, the enhanced aerosol water content (Fig. 12) caused by the production of hydrophilic species, e.g., sulfate, may also play a role in accelerating the $\mathrm{NO}_{2}$ conversion (Stutz et al., 2004). Another factor that might have enhanced HONO production could be the formation of some specific secondary material on BB particles, e.g., sulfate (Kleffmann et al., 1998) and secondary organic aerosols (Bröske et al., 2003).

\section{Conclusions and implications}

In this study, we analyzed a two-month measurement of atmospheric HONO during the BB season of 2012 (May and June) at the SORPES station in the western YRD of eastern China, and demonstrated an important role of BB in the HONO chemistry in the ambient atmosphere. Direct emissions from $\mathrm{BB}$ have been estimated to contribute $17 \% \pm 12 \%$ of the observed HONO concentrations during nighttime BB episodes. The other over $80 \%$ was produced by the heterogeneous conversion of $\mathrm{NO}_{2}$. The $\mathrm{NO}_{2}$-to-HONO $\left(C_{\mathrm{HONO}}\right)$ conversion rates were detected to be significantly elevated during the BB periods due to the combined effect of enhanced particle loadings, larger specific surface areas of particles and higher $\mathrm{NO}_{2}$ conversion efficiency on $\mathrm{BB}$ aerosols. An episode of mixed plumes of intense BB and anthropogenic FF emissions was observed on the 10 June, during which the $\mathrm{HONO}$ production potentials from the conversion of $\mathrm{NO}_{2}$ was further promoted by the formation of secondary particulate matter on BB particles.

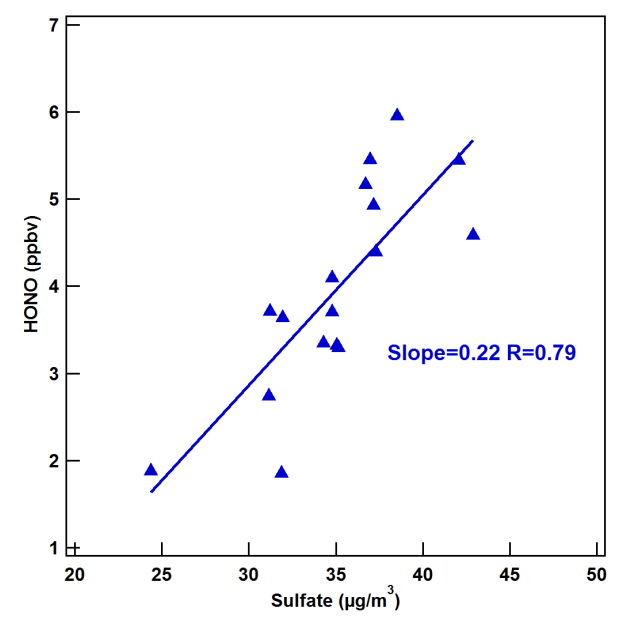

Figure 13. Scatter plot between HONO and sulfate concentration in $\mathrm{PM}_{2.5}$ during the nighttime on the 10 June.

Given that BB plumes are easily mixed with other anthropogenic pollutants in eastern China, their influence on the atmospheric chemistry is expected to be important via affecting the HONO budget and thus the radical pool. Furthermore, considering the potential re-activation of BB particles (e.g., soot) during their atmospheric transport, the HONO chemistry associated with BB plumes may affect atmospheric chemistry for long distances downwind of BB areas, even in the marine boundary layer. Therefore, more studies are encouraged on BB related chemistry in eastern China, which is a unique "laboratory" with frequent mixed plumes of BB and anthropogenic pollution.

Acknowledgements. This work was funded by National Natural Science Foundation of China (D0512/41305123 and D0510/41275129), the MOST 973 Program (2010CB428500), and the Jiangsu Provincial Science Fund for Distinguished Young Scholars (No. BK20140021). We thank T. Wang and L. Xue at The Hong Kong Polytechnic University for their suggestion on the data analysis. We are grateful of J. Kleffmann at Bergische Universität Wuppertal for his useful discussions on the data quality. We thank Metrohm Co. China for providing the MARGA analyzer and Z. Yan and J. Gao for their technical support for the instrument. We also thank the two anonymous referees and the editor for their construction and detailed comments during the review of this manuscript.

Edited by: J. Roberts 


\section{References}

Acker, K. and Möller, D.: Atmospheric variation of nitrous acid at different sites in Europe, Environ. Chem., 4, 242-255, doi:10.1071/EN07023, 2007.

Alicke, B., Platt, U., and Stutz, J.: Impact of nitrous acid photolysis on the total hydroxyl radical budget during the Limitation of Oxidant Production/Pianura Padana Produzione di Ozono study in Milan, J. Geophys. Res.-Atmos., 107, 8196, doi:10.1029/2000JD000075, 2002.

Ammann, M., Kalberer, M., Jost, D. T., Tobler, L., Rössler, E., Piguet, D., Gäggeler, H. W., and Baltensperger, U.: Heterogeneous production of nitrous acid on soot in polluted air masses, Nature, 395, 157-160, 1998.

Ammann, M., Rössler, E., Strekowski, R., and George, C.: Nitrogen dioxide multiphase chemistry: Uptake kinetics on aqueous solutions containing phenolic compounds, Phys. Chem. Chem. Phys., 7, 2513-2518, 2005.

Andreae, M. O.: Soot carbon and excess fine potassium: long-range transport of combustion-derived aerosols, Science, 220, 11481151, doi:10.1126/science.220.4602.1148, 1983.

Andreae, M. O. and Merlet, P.: Emission of trace gases and aerosols from biomass burning, Global Biogeochem. Cy., 15, 955-966, doi:10.1029/2000gb001382, 2001

Appel, B. R., Winer, A. M., Tokiwa, Y., and Biermann, H. W.: Comparison of atmospheric nitrous acid measurements by annular denuder and differential optical absorption systems, Atmos. Environ. A-Gen, 24, 611-616, doi:10.1016/0960-1686(90)90016-G, 1990.

Aubin, D. G. and Abbatt, J. P. D.: Interaction of $\mathrm{NO}_{2}$ with hydrocarbon soot: focus on HONO yield, surface modification, and mechanism, J. Phys. Chem. A, 111, 6263-6273, doi:10.1021/jp068884h, 2007.

Aumont, B., Madronich, S., Ammann, M., Kalberer, M., Baltensperger, U., Hauglustaine, D., and Brocheton, F.: On the $\mathrm{NO}_{2}+$ soot reaction in the atmosphere, J. Geophys. Res.-Atmos., 104, 1729-1736, doi:10.1029/1998jd100023, 1999.

Barnes, I. and Rudziński, K. J.: Disposal of Dangerous Chemicals in Urban Areas and Mega Cities - Role of Oxides and Acids of Nitrogen in Atmospheric Chemistry, Springer, 2012.

Bedjanian, Y. and El Zein, A.: Interaction of $\mathrm{NO}_{2}$ with $\mathrm{TiO}_{2}$ surface under UV irradiation: products study, J. Phys. Chem. A, 116, 1758-1764, doi:10.1021/jp210078b, 2012.

Bröske, R., Kleffmann, J., and Wiesen, P.: Heterogeneous conversion of $\mathrm{NO}_{2}$ on secondary organic aerosol surfaces: A possible source of nitrous acid (HONO) in the atmosphere?, Atmos. Chem. Phys., 3, 469-474, doi:10.5194/acp-3-469-2003, 2003.

Burling, I. R., Yokelson, R. J., Griffith, D. W. T., Johnson, T. J., Veres, P., Roberts, J. M., Warneke, C., Urbanski, S. P., Reardon, J., Weise, D. R., Hao, W. M., and de Gouw, J.: Laboratory measurements of trace gas emissions from biomass burning of fuel types from the southeastern and southwestern United States, Atmos. Chem. Phys., 10, 11115-11130, doi:10.5194/acp10-11115-2010, 2010.

Cai, J., Lu, N., and Sorensen, C. M.: Comparison of size and morphology of soot aggregates as determined by light scattering and electron microscope analysis, Langmuir, 9, 2861-2867, doi:10.1021/la00035a023, 1993.

Capes, G., Johnson, B., McFiggans, G., Williams, P. I., Haywood, J., and Coe, H.: Aging of biomass burning aerosols over West
Africa: Aircraft measurements of chemical composition, microphysical properties, and emission ratios, J. Geophys. Res.Atmos., 113, D00C15, doi:10.1029/2008JD009845, 2008.

Ding, A. J., Wang, T., and Fu, C. B.: Transport characteristics and origins of carbon monoxide and ozone in Hong Kong, South China, J. Geophys. Res.-Atmos., 118, 9475-9488, doi:10.1002/jgrd.50714, 2013a.

Ding, A. J., Fu, C. B., Yang, X. Q., Sun, J. N., Petäjä, T., Kerminen, V. M., Wang, T., Xie, Y., Herrmann, E., Zheng, L. F., Nie, W., Liu, Q., Wei, X. L., and Kulmala, M.: Intense atmospheric pollution modifies weather: a case of mixed biomass burning with fossil fuel combustion pollution in eastern China, Atmos. Chem. Phys., 13, 10545-10554, doi:10.5194/acp-1310545-2013, 2013b.

Ding, A. J., Fu, C. B., Yang, X. Q., Sun, J. N., Zheng, L. F., Xie, Y. N., Herrmann, E., Nie, W., Petäjä, T., Kerminen, V. M., and Kulmala, M.: Ozone and fine particle in the western Yangtze River Delta: an overview of $1 \mathrm{yr}$ data at the SORPES station, Atmos. Chem. Phys., 13, 5813-5830, doi:10.5194/acp-13-58132013, 2013c.

Dobbins, R. A., and Megaridis, C. M.: Morphology of flamegenerated soot as determined by thermophoretic sampling, Langmuir, 3, 254-259, 1987.

Donaldson, M. A., Berke, A. E., and Raff, J. D.: Uptake of gas phase nitrous acid onto boundary layer soil surfaces, Environ. Sci. Technol., 48, 375-383, doi:10.1021/es404156a, 2013.

Elshorbany, Y., Barnes, I., Becker, K. H., Kleffmann, J., and Wiesen, P.: Sources and cycling of tropospheric hydroxyl radicals - an overview, Int. J. Res. Phys. Chem. Chem. Phys., 224, 967-987, 2010.

Elshorbany, Y. F., Steil, B., Brühl, C., and Lelieveld, J.: Impact of HONO on global atmospheric chemistry calculated with an empirical parameterization in the EMAC model, Atmos. Chem. Phys., 12, 9977-10000, doi:10.5194/acp-12-9977-2012, 2012.

Elshorbany, Y. F., Crutzen, P. J., Steil, B., Pozzer, A., Tost, H., and Lelieveld, J.: Global and regional impacts of HONO on the chemical composition of clouds and aerosols, Atmos. Chem. Phys., 14, 1167-1184, doi:10.5194/acp-14-1167-2014, 2014.

Genfa, Z., Slanina, S., Brad Boring, C., Jongejan, P. A. C., and Dasgupta, P. K.: Continuous wet denuder measurements of atmospheric nitric and nitrous acids during the 1999 Atlanta Supersite, Atmos. Environ., 37, 1351-1364, doi:10.1016/S13522310(02)01011-7, 2003.

George, C., Strekowski, R. S., Kleffmann, J., Stemmler, K., and Ammann, M.: Photoenhanced uptake of gaseous $\mathrm{NO}_{2}$ on solid organic compounds: a photochemical source of HONO?, Faraday Discuss., 130, 195-210, doi:10.1039/b417888m, 2005.

Gonçalves, M., Dabdub, D., Chang, W. L., Jorba, O., and Baldasano, J. M.: Impact of HONO sources on the performance of mesoscale air quality models, Atmos. Environ., 54, 168-176, doi:10.1016/j.atmosenv.2012.02.079, 2012.

Harrison, R. M. and Collins, G. M.: Measurements of reaction coefficients of $\mathrm{NO}_{2}$ and $\mathrm{HONO}$ on aerosol particles, J. Atmos Chem., 30, 397-406, doi:10.1023/a:1006094304069, 1998.

Harrison, R. M. and Kitto, A.-M. N.: Evidence for a surface source of atmospheric nitrous acid, Atmos. Environ., 28, 1089-1094, doi:10.1016/1352-2310(94)90286-0, 1994.

Hofzumahaus, A., Rohrer, F., Lu, K., Bohn, B., Brauers, T., Chang, C.-C., Fuchs, H., Holland, F., Kita, K., Kondo, Y., Li, X., Lou, 
S., Shao, M., Zeng, L., Wahner, A., and Zhang, Y.: Amplified trace gas removal in the troposphere, Science, 324, 1702-1704, doi:10.1126/science.1164566, 2009.

Janhäll, S., Andreae, M. O., and Pöschl, U.: Biomass burning aerosol emissions from vegetation fires: particle number and mass emission factors and size distributions, Atmos. Chem. Phys., 10, 1427-1439, doi:10.5194/acp-10-1427-2010, 2010.

Kalberer, M., Ammann, M., Arens, F., Gäggeler, H. W., and Baltensperger, U.: Heterogeneous formation of nitrous acid (HONO) on soot aerosol particles, J. Geophys. Res.-Atmos., 104, 1382513832, doi:10.1029/1999jd900141, 1999.

Kleffmann, J., Becker, K. H., and Wiesen, P.: Heterogeneous $\mathrm{NO}_{2}$ conversion processes on acid surfaces: possible atmospheric implications, Atmos. Environ., 32, 2721-2729, doi:10.1016/S13522310(98)00065-X, 1998.

Kleffmann, J., Becker, K. H., Lackhoff, M., and Wiesen, P.: Heterogeneous conversion of $\mathrm{NO}_{2}$ on carbonaceous surfaces, Phys. Chem. Chem. Phys., 1, 5443-5450, doi:10.1039/a905545b, 1999.

Kleffmann, J., Heland, J., Kurtenbach, R., Lorzer, J., and Wiesen, P.: A new instrument (LOPAP) for the detection of nitrous acid (HONO), Environ. Sci. Pollut. R., 48-54, 2002.

Kleffmann, J., Gavriloaiei, T., Hofzumahaus, A., Holland, F., Koppmann, R., Rupp, L., Schlosser, E., Siese, M., and Wahner, A.: Daytime formation of nitrous acid: A major source of $\mathrm{OH}$ radicals in a forest, Geophys. Res. Lett., 32, L05818, doi:10.1029/2005GL022524, 2005.

Kleffmann, J. and Wiesen, P.: Heterogeneous conversion of $\mathrm{NO}_{2}$ and $\mathrm{NO}$ on $\mathrm{HNO}_{3}$ treated soot surfaces: atmospheric implications, Atmos. Chem. Phys., 5, 77-83, doi:10.5194/acp-5-772005, 2005.

Kleffmann, J.: Daytime sources of nitrous acid (HONO) in the atmospheric boundary layer, Chem. Phys. Chem., 8, 1137-1144, 2007.

Kurtenbach, R., Becker, K. H., Gomes, J. A. G., Kleffmann, J., Lörzer, J. C., Spittler, M., Wiesen, P., Ackermann, R., Geyer, A., and Platt, U.: Investigations of emissions and heterogeneous formation of HONO in a road traffic tunnel, Atmos. Environ., 35, 3385-3394, doi:10.1016/S1352-2310(01)00138-8, 2001.

Langridge, J. M., Gustafsson, R. J., Griffiths, P. T., Cox, R. A., Lambert, R. M., and Jones, R. L.: Solar driven nitrous acid formation on building material surfaces containing titanium dioxide: A concern for air quality in urban areas?, Atmos. Environ., 43, 51285131, doi:10.1016/j.atmosenv.2009.06.046, 2009.

Li, G., Lei, W., Zavala, M., Volkamer, R., Dusanter, S., Stevens, P., and Molina, L. T.: Impacts of HONO sources on the photochemistry in Mexico City during the MCMA-2006/MILAGO Campaign, Atmos. Chem. Phys., 10, 6551-6567, doi:10.5194/acp-106551-2010, 2010.

Li, J., Pósfai, M., Hobbs, P. V., and Buseck, P. R.: Individual aerosol particles from biomass burning in southern Africa: 2, Compositions and aging of inorganic particles, J. Geophys. Res.-Atmos., 108, 8484, doi:10.1029/2002JD002310, 2003.

Li, X., Wang, S., Duan, L., Hao, J., Li, C., Chen, Y., and Yang, L.: Particulate and trace gas emissions from open burning of wheat straw and corn stover in China, Environ. Sci. Technol., 41, 60526058, doi:10.1021/es0705137, 2007.

Li, X., Brauers, T., Häseler, R., Bohn, B., Fuchs, H., Hofzumahaus, A., Holland, F., Lou, S., Lu, K. D., Rohrer, F., Hu, M., Zeng, L.
M., Zhang, Y. H., Garland, R. M., Su, H., Nowak, A., Wiedensohler, A., Takegawa, N., Shao, M., and Wahner, A.: Exploring the atmospheric chemistry of nitrous acid (HONO) at a rural site in Southern China, Atmos. Chem. Phys., 12, 1497-1513, doi:10.5194/acp-12-1497-2012, 2012.

Longfellow, C. A., Ravishankara, A. R., and Hanson, D. R.: Reactive uptake on hydrocarbon soot: Focus on $\mathrm{NO}_{2}$, J. Geophys. Res.-Atmos., 104, 13833-13840, doi:10.1029/1999jd900145, 1999.

Ma, Y., Weber, R. J., Lee, Y. -N., Orsini, D. A., Maxwell-Meier, K., Thornton, D. C., Bandy, A. R., Clarke, A. D., Blake, D. R., Sachse, G. W., Fuelberg, H. E., Kiley, C. M., Woo, J. -H., Streets, D. G., and Carmichael, G. R.: Characteristics and influence of biosmoke on the fine-particle ionic composition measured in Asian outflow during the Transport and Chemical Evolution Over the Pacific (TRACE-P) experiment, J. Geophys. Res.Atmos., 108, 8816, doi:10.1029/2002JD003128, 2003.

Makkonen, U., Virkkula, A., Mäntykenttä, J., Hakola, H., Keronen, P., Vakkari, V., and Aalto, P. P.: Semi-continuous gas and inorganic aerosol measurements at a Finnish urban site: comparisons with filters, nitrogen in aerosol and gas phases, and aerosol acidity, Atmos. Chem. Phys., 12, 5617-5631, doi:10.5194/acp-125617-2012, 2012.

Monge, M. E., D’Anna, B., Mazri, L., Giroir-Fendler, A., Ammann, M., Donaldson, D. J., and George, C.: Light changes the atmospheric reactivity of soot, P. Natl. Acad. Sci. USA, 107, 66056609, doi:10.1073/pnas.0908341107, 2009.

Muller, Th., Dubois, R., Spindler, G., Bruggemann, E., Ackermann, R., Geyer, A., and Platf, U.: Measurements of nitrous acid by DOAS and diffusion denuders: a comparison, Trans. Ecol. Environ., 28, doi:10.2495/EURO990681, 1999.

Ndour, M., D’Anna, B., George, C., Ka, O., Balkanski, Y., Kleffmann, J., Stemmler, K., and Ammann, M.: Photoenhanced uptake of $\mathrm{NO}_{2}$ on mineral dust: Laboratory experiments and model simulations, Geophys. Res. Lett., 35, L05812, doi:10.1029/2007g1032006, 2008.

Nie, W., Wang, T., Xue, L. K., Ding, A. J., Wang, X. F., Gao, X. M., Xu, Z., Yu, Y. C., Yuan, C., Zhou, Z. S., Gao, R., Liu, X. H., Wang, Y., Fan, S. J., Poon, S., Zhang, Q. Z., and Wang, W. X.: Asian dust storm observed at a rural mountain site in southern China: chemical evolution and heterogeneous photochemistry, Atmos. Chem. Phys., 12, 11985-11995, doi:10.5194/acp12-11985-2012, 2012.

Platt, U., Perner, D., Harris, G. W., Winer, A. M., and Pitts, J. N.: Observations of nitrous acid in an urban atmosphere by differential optical absorption, Nature, 285, 312-314, doi:10.1038/285312a0, 1980.

Prince, A. P., Wade, J. L., Grassian, V. H., Kleiber, P. D., and Young, M. A.: Heterogeneous reactions of soot aerosols with nitrogen dioxide and nitric acid: atmospheric chamber and Knudsen cell studies, Atmos. Environ., 36, 5729-5740, doi:10.1016/S13522310(02)00626-X, 2002.

Reid, J. S., Koppmann, R., Eck, T. F., and Eleuterio, D. P.: A review of biomass burning emissions part II: intensive physical properties of biomass burning particles, Atmos. Chem. Phys., 5, 799825, doi:10.5194/acp-5-799-2005, 2005.

Roberts, J. M., Veres, P., Warneke, C., Neuman, J. A., Washenfelder, R. A., Brown, S. S., Baasandorj, M., Burkholder, J. B., Burling, I. R., Johnson, T. J., Yokelson, R. J., and de Gouw, J.: 
Measurement of HONO, HNCO, and other inorganic acids by negative-ion proton-transfer chemical-ionization mass spectrometry (NI-PT-CIMS): application to biomass burning emissions, Atmos. Meas. Tech., 3, 981-990, doi:10.5194/amt-3-981-2010, 2010

Sander, S. P., Golden, D., Kurylo, M., Moortgat, G., Wine, P., Ravishankara, A., Kolb, C., Molina, M., Finlayson-Pitts, B., and Huie, R.: Chemical kinetics and photochemical data for use in atmospheric studies evaluation number 15, 2006.

Simoneit, B. R. T.: Biomass burning - a review of organic tracers for smoke from incomplete combustion, Appl. Geochem., 17, 129162, doi:10.1016/S0883-2927(01)00061-0, 2002.

Sörgel, M., Regelin, E., Bozem, H., Diesch, J. M., Drewnick, F., Fischer, H., Harder, H., Held, A., Hosaynali-Beygi, Z., Martinez, M., and Zetzsch, C.: Quantification of the unknown HONO daytime source and its relation to $\mathrm{NO}_{2}$, Atmos. Chem. Phys., 11, 10433-10447, doi:10.5194/acp-11-10433-2011, 2011.

Spindler, G., Hesper, J., Brüggemann, E., Dubois, R., Müller, Th., and Herrmann, H.: Wet annular denuder measurements of nitrous acid: laboratory study of the artefact reaction of $\mathrm{NO}_{2}$ with $\mathrm{S}(\mathrm{IV})$ in aqueous solution and comparison with field measurements, Atmos. Environ., 37, 2643-2662, doi:10.1016/S13522310(03)00209-7, 2003.

Stemmler, K., Ammann, M., Donders, C., Kleffmann, J., and George, C.: Photosensitized reduction of nitrogen dioxide on humic acid as a source of nitrous acid, Nature, 440, 195-198, 2006.

Stockwell, C. E., Yokelson, R. J., Kreidenweis, S. M., Robinson, A. L., DeMott, P. J., Sullivan, R. C., Reardon, J., Ryan, K. C., Griffith, D. W. T., and Stevens, L.: Trace gas emissions from combustion of peat, crop residue, domestic biofuels, grasses, and other fuels: configuration and Fourier transform infrared (FTIR) component of the fourth Fire Lab at Missoula Experiment (FLAME4), Atmos. Chem. Phys., 14, 9727-9754, doi:10.5194/acp-149727-2014, 2014.

Stutz, J., Alicke, B., and Neftel, A.: Nitrous acid formation in the urban atmosphere: gradient measurements of $\mathrm{NO}_{2}$ and $\mathrm{HONO}$ over grass in Milan, Italy, J. Geophys. Res.-Atmos, 107, 8192, doi:10.1029/2001JD000390, 2002.

Stutz, J., Alicke, B., Ackermann, R., Geyer, A., Wang, S., White, A. B., Williams, E. J., Spicer, C. W., and Fast, J. D.: Relative humidity dependence of HONO chemistry in urban areas, J. Geophys. Res.-Atmos., 109, D03307, doi:10.1029/2003JD004135, 2004.
Su, H.: HONO: a study to its sources and impacts from field measurements at the sub-urban areas of PRD region, $\mathrm{PhD}$ Thesis, Peking University, 2008.

Su, H., Cheng, Y. F., Shao, M., Gao, D. F., Yu, Z. Y., Zeng, L. M., Slanina, J., Zhang, Y. H., and Wiedensohler, A.: Nitrous acid (HONO) and its daytime sources at a rural site during the 2004 PRIDE-PRD experiment in China, J. Geophys. Res.Atmos., 113, D14312, doi:10.1029/2007jd009060, 2008.

Su, H., Cheng, Y., Oswald, R., Behrendt, T., Trebs, I., Meixner, F. X., Andreae, M. O., Cheng, P., Zhang, Y., and Pöschl, U.: Soil nitrite as a source of atmospheric $\mathrm{HONO}$ and $\mathrm{OH}$ radicals, Science, 333, 1616-1618, doi:10.1126/science.1207687, 2011.

VandenBoer, T. C., Brown, S. S., Murphy, J. G., Keene, W. C., Young, C. J., Pszenny, A. A. P., Kim, S., Warneke, C., de Gouw, J. A., Maben, J. R., Wagner, N. L., Riedel, T. P., Thornton, J. A., Wolfe, D. E., Dubé, W. P., Öztürk, F., Brock, C. A., Grossberg, N., Lefer, B., Lerner, B., Middlebrook, A. M., and Roberts, J. M.: Understanding the role of the ground surface in HONO vertical structure: High resolution vertical profiles during NACHTT-11, J. Geophys. Res.-Atmos., 118, 10155-10171, doi:10.1002/jgrd.50721, 2013.

Veres, P., Roberts, J. M., Burling, I. R., Warneke, C., de Gouw, J., and Yokelson, R. J.: Measurements of gas-phase inorganic and organic acids from biomass fires by negative-ion protontransfer chemical-ionization mass spectrometry, J. Geophys Res.-Atmos., 115, D23302, doi:10.1029/2010jd014033, 2010.

Wang, S., Zhou, R., Zhao, H., Wang, Z., Chen, L., and Zhou, B.: Long-term observation of atmospheric nitrous acid (HONO) and its implication to local $\mathrm{NO}_{2}$ levels in Shanghai, China, Atmos. Environ., 77, 718-724, doi:10.1016/j.atmosenv.2013.05.071, 2013.

Wang, T., Wong, C. H., Cheung, T. F., Blake, D. R., Arimoto, R., Baumann, K., Tang, J., Ding, G. A., Yu, X. M., Li, Y. S., Streets, D. G., and Simpson, I. J.: Relationships of trace gases and aerosols and the emission characteristics at Lin'an, a rural site in east ern China, during spring 2001, J. Geophys. Res.Atmos., 109, D19S05, doi:10.1029/2003JD004119, 2004.

Xu, Z., Wang, T., Xue, L. K., Louie, P. K. K., Luk, C. W. Y., Gao, J., Wang, S. L., Chai, F. H., and Wang, W. X.: Evaluating the uncertainties of thermal catalytic conversion in measuring atmospheric nitrogen dioxide at four differently polluted sites in China, Atmos. Environ., 76, 221-226, doi:10.1016/j.atmosenv.2012.09.043, 2013. 